\title{
International MDS Working Groups: a model of success to improve diagnosis and treatment in rare diseases: 10-year jubilee of the Austrian MDS platform
}

\author{
Michael Pfeilstöcker
}

Received: 31 July 2014 / Accepted: 5 August 2014 / Published online: 22 August 2014

(C) Springer-Verlag Wien 2014

The year 2013 marked the 10th anniversary of the Myelodysplastic Syndromes (MDS) Platform of the Austrian Society for Hematology and Oncology. Although there had already been previously scientific contributions to this field, in 2003, the founding members of the platform concluded that combined efforts of all MDS researchers in Austria would promote the outcome and recognition of this work and improve clinical management of MDS patients. To celebrate this anniversary, an educational meeting in November 2013 provided a "state of the art" overview in MDS and was also a good opportunity to analyze the benefits of collaborative work and to plan future projects.

A specific feature of the Austrian MDS platform is its informal character. Each member may propose projects that are discussed within the platform, and centers are free to participate. Another key point is connecting the platform to other MDS collaborative groups. As our experience shows, integration in larger groups such as the German-Austrian-Swiss group or the International Working Group on Prognostic Models offers the opportunity for leading contributions (not only data acquisition) in international projects $[1,2]$. In contrast, the MDS platform offers a network for projects adequate for small countries, when the critical mass of data leading to meaningful results can be achieved within its local members $[3,4]$.

Why do we need scientific groups such as the Austrian MDS platform?

Two reasons may be identified: the first is the low incidence of rare diseases such as MDS, with consequently lower prevalence in smaller countries, and the second is

Univ.-Prof. Dr. M. Pfeilstöcker, MBA ( $\square)$

3rd Medical Department, Hanusch Hospital,

Heinrich-Collin-Straße 30,

1140 Vienna, Austria

e-mail: michael.pfeilstoecker@meduniwien.ac.at the heterogeneity of a disease-which is very prominent in MDS-but this may also apply to more common diseases when molecular heterogeneity becomes unveiled. Therefore, projects addressing diagnostic and prognostic markers are reasonable topics for collaborative working groups: the platform has led a consensus conference leading to a widely cited paper on diagnostic criteria in MDS [5]; furthermore, it has been instrumental in designing the new international standard in prognostication [1].

New therapeutic standards derive from randomized trials. Numbers of patients enrolled have to be large, especially in heterogeneous entities such as MDS. These numbers can only be achieved by multicenter trials, which are mostly sponsored by the pharmaceutical industry. Groups as the MDS platform may identify patients to be recruited, and platform registries can be used to describe the real-life effects of new therapies [4]. For independent research, it would be desirable if academic groups linked together in working groups would embark on investigator-initiated trials more often. Facilitation of these projects is one of the main goals of the MDS platform in the near future.

Scientific advances and good medical practice are interconnected when knowledge and scientific ambition diffuse into the general management of MDS patients. Activities in this field are also promoted by the platform as in the establishment and implementation of therapeutic standards [6] and as the distributor of knowledge providing information for physicians and patients.

Although not a scientific aspect, working groups offer the opportunity of confidence building. Science is competitive in its essence, but valuable results need intellectual and practical cooperation.

In conclusion, the Austrian MDS platform is an example for many active and successful groups working in different fields, with many obtaining their success from recipes described earlier in the text. 


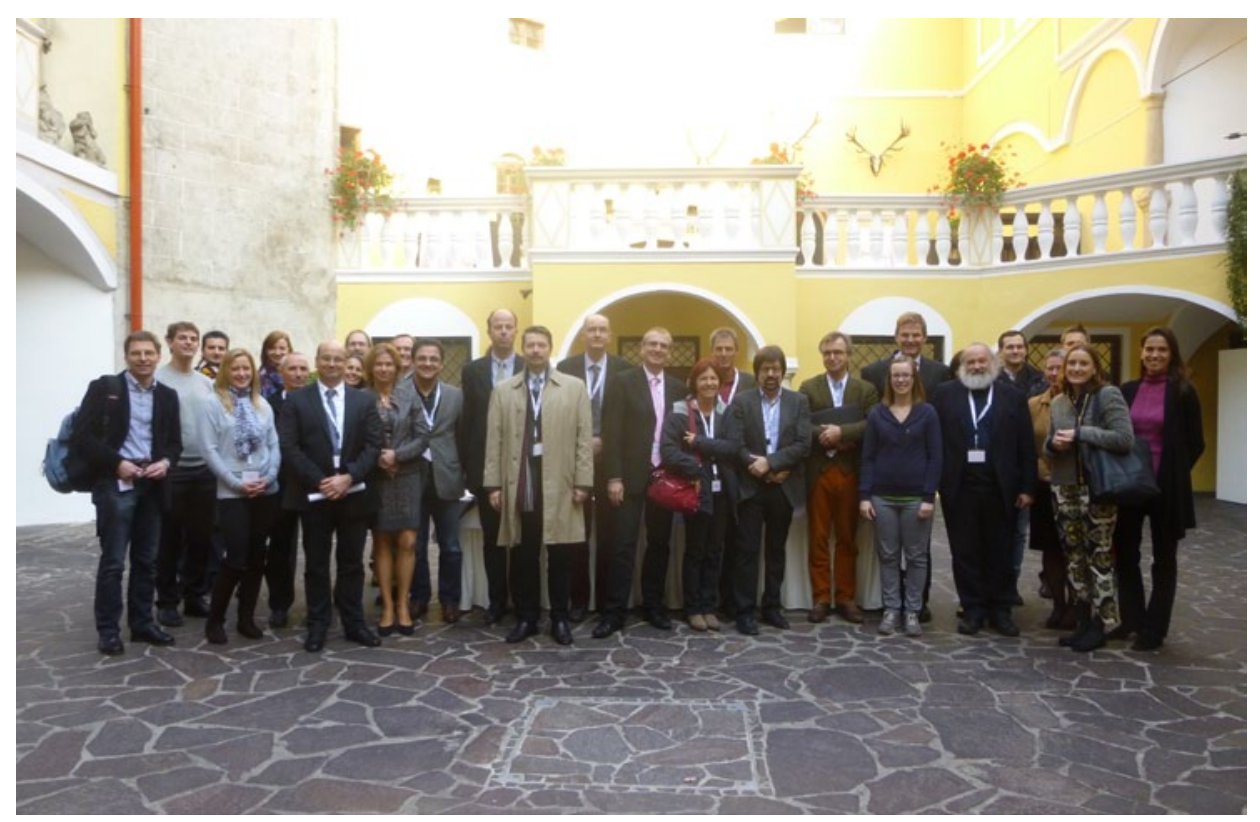

\section{Acknowledgments}

The author would like to acknowledge the continuous logistic support from the Austrian Society for Hematology and Oncology for the Austrian MDS platform.

\section{Conflict of interest}

There is no conflict of interest to declare.

\section{References}

1. Greenberg PL, Tuechler H, Schanz J, Sanz G, GarciaManero G, Solé F, Bennett JM, Bowen D, Fenaux P, Dreyfus F, Kantarjian H, Kuendgen A, Levis A, Malcovati L, Cazzola M, Cermak J, Fonatsch C, Le Beau MM, Slovak ML, Krieger O, Luebbert M, Maciejewski J, Magalhaes SM, Miyazaki Y, Pfeilstöcker M, Sekeres M, Sperr WR, Stauder R, Tauro S, Valent P, Vallespi T, van de Loosdrecht AA, Germing U, Haase D. Revised international prognostic scoring system for myelodysplastic syndromes. Blood. 2012;120(12):245465. PubMed PMID: 22740453.

2. Nösslinger T, Tüchler H, Germing U, Sperr WR, Krieger O, Haase D, Lübbert M, Stauder R, Giagounidis A, Valent $\mathrm{P}$, Pfeilstöcker M. Prognostic impact of age and gender in 897 untreated patients with primary myelodysplastic syndromes. Ann Oncol. 2010;21(1):120-5. doi:10.1093/ annonc/mdp264. PubMed PMID: 19605511.
3. Pleyer L, Burgstaller S, Girschikofsky M, Linkesch W, Stauder R, Pfeilstöcker M, Schreder M, Tinchon C, Sliwa T, Lang A, Sperr WR, Krippl P, Geissler D, Voskova D, Schlick K, Thaler J, Machherndl-Spandl S, Theiler G, Eckmüllner O, Greil R. Azacitidine in 302 patients with WHO-defined acute myeloid leukemia: results from the Austrian Azacitidine Registry of the AGMT-Study Group. Ann Hematol. 2014 June 21. Epub ahead of print. PubMed PMID: 24951123.

4. Stauder R, Nösslinger T, Pfeilstöcker M, Sperr WR, Wimazal F, Krieger O, Valent P. Impact of age and comorbidity in myelodysplastic syndromes. J Natl Compr Canc Netw. 2008;6(9):927-34. Review. PubMed PMID: 18926101.

5. Valent P, Horny HP, Bennett JM, Fonatsch C, Germing U, Greenberg P, Haferlach T, Haase D, Kolb HJ, Krieger O, Loken M, van de Loosdrecht A, Ogata K, Orfao A, Pfeilstöcker M, Rüter B, Sperr WR, Stauder R, Wells DA. Definitions and standards in the diagnosis and treatment of the myelodysplastic syndromes: consensus statements and report from a working conference. Leuk Res. 2007;31(6):727-36. Review. PubMed PMID: 17257673.

6. Stauder R, Wimazal F, Nösslinger T, Krieger O, Sperr WR, Sill H, Pfeilstöcker M, Valent P. [Individualized management and therapy of myelodysplastic syndromes]. Wien Klin Wochenschr. 2008;120(17-18):523-37. Review. German. doi:10.1007/s00508-008-1058-6. PubMed PMID: 18988005. 